\title{
KONSEP PENGALAMAN KEAGAMAAN JOACHIM WACH
}

\author{
Triyani Pujiastuti*
}

\section{Abstract}

This paper tries to expose Joachim Wach's view of religious experience. Religious experience is a human activity in its existence with the creator. Religious experience arises when a person has practiced religious teachings so that they are inward and outward. The religious experience of one individual to another varies depending on how he practices his or her religion.

Kata Kunci: Pengalaman, Keagamaan dan Joachim Wach

\section{Pendahuluan}

Memiliki suatu agama atau keyakinan merupakan hak dasar kita sebagai manusia. Dimana kita dapat menerapkan ajaran agama tersebut pada kehidupan kita sehari-hari tanpa paksaan dan pengaruh dari orang lain.

Agama dianggap sebagai suatu jalan hidup bagi manusia menuntun manusia agar hidupnya tidak kacau, agama berfungsi untuk memelihara integritas manusia dalammembina hubungan dengan Tuhan dan hubungan dengan sesama manusia dan dengan alam yang mengitarinya. ${ }^{1}$ Hubungan batin seseorang dengan Allah SWT di dalam ilmu jiwa dinamakan pengalaman keagamaan. Hubungan batin ini timbul setelah seseorang melakukan ajaran-ajaran agama atau kegiatan keagamaan, disamping itu dari pengalaman keagamaan tersebut akan berbeda antara orang yang satu dengan yang lainnya, hal ini akan dirasakan oleh mereka tergantung pada pengalaman keagamaan masing-masing dalam menjalankan kehidupan beragama.

Dalam mengamalkan ritual agama Jaochim Wach mengungkapkan bahwa manusia memiliki pemahaman dan pengalaman yang berbeda-beda, sehingga dalam pengalamannya pun terdapat perbedaan sesuai dengan tanggapan dan penghayatannya serta pelaksanaan aktual keberagamaannya dan bagaimana aspek dirinya dan fikirannya dengan Tuhannya. ${ }^{2}$

Dalam ranah psikologi agama, pengalaman keagamaan (religious expereince) sebagaimana terjadi pada diri AlGhazali dan Ibnu Arabi selalu berkaitan dengan kesadaran beragama (religious counsciousness). Kesadaran agama hadir dalam pikiran yang merupakan aspek mental dari aktivitas agama, sementara pengalaman keagamaan merupakan unsur perasaan dalam kesadaran beragama, yakni perasaan yang membawa kepada keyakinan yang dihasilkan oleh tindakan (amaliyah). ${ }^{3}$

Secara historis, pengalaman keagamaan sebagai wacana dalam psikologi agama hadir di akhir abad ke 17, ketika filosof Jerman Schleiermacher (1768-1834) menganggapnya sebagai substansi agama. Perhatian para filosof agama pada wacana 
tersebut, merupakan perubahan pemikiran di era modern, yang memiliki ciri: (1) humanisme, dalam artian bahwa ukuran segalanya adalah manusia; dan (2) sangat bertumpu pada kekuatan rasionalisme. Di antara filosof yang ada, Hume termasuk salah satu tokoh yang memiliki peranan besar.

Hume menganggap bahwa argumen dalam membuktikan Tuhan tidaklah sempurna. Trinitas dianggap sebagai sebuah perkara yang tidak memiliki argumen sama sekali. Ilmu pengetahuan dan doktrin-doktrin gereja adalah dua hal yang tidak pernah ketemu. Imanuel Kant juga memahami bahwa agama tidak sejalan dengan Rasionalisme Radikal, Kant menerima pandangan Hume yang meyakini bahwa doktrin-doktrin agama tidak bisa dibuktikan dengan akal, bahkan Kant lebih lihai daripada Hume dalam menjelaskan hal tersebut. Alternatif yang diberikan Kant bahwa agama harus dikeluarkan dari wilayah akal-teoritis, dan memasukkan kepada wilayah akal-praktis, yaitu akhlak. Kant meyakini Tuhan hanya bisa dibuktikan dengan akal-praktis, yaitu dalam wilayah akhlak, tidak dengan argumen yang dibangun oleh akal teoritis dalam membuktikan keberadaan Tuhan.

Dalam Islam, pengalaman keagamaan adalah jalan biasa yang ditempuh para pencari Tuhan.Al-Ghazali misalnya, menjadikan jalan tasawuf yang dipenuhi pengalaman keagamaan pribadinya sebagai jalan terakhir dalam pencarian terbaik menuju Tuhansetelah bimbang dan ragu (skeptis) terhadap kebenaran filsafat. Demikian juga IbnuArabi, penggagas Wahdat al-Wujud, mendapatkan inspirasi menulis kitab Fushûsh al-Hikâm setelah pengalaman spiritualnya bertemu Nabi Muammad SAW.

\section{Biografi Singkat Joachim Wach}

Joachim Wach, putra tertua Felix dengan Katherine Wach, di lahirkan 25 Januari 1898 di Chemintz, Saxony. Ayahnya adalah putra dari Adolf Wach dan Lily Mendelssohn Bartholdy Wach. Lily adalah putrid termuda seorang komponis, Felix Mendelsshon Bartholdy. Adolf Wach mengajar hokum di Rostock dan kemudian di Lepizig.

Joachim Wach adalah keturunan dari keluarga Mendelssohn Bartholdy baik dari garis ibu ataupun ayahnya. Katherine, sang ibu yang meninggal dunia pada musim panas tahun 1956 adalah cucu perempuan Paul Mendelssohn-Bartholdy, saudara laki-laki Felix. Garis keayahnya dari Mendelssohn (garis komponis) memakai nama tampa penghubung, sementara garis keibuannya (garis Paul) mempergunakan nama dengan tanda penghubung antara kedua nama tersebut. Kedua garis tersebut berpangkal pada filososfYahudi yang besar, yaitu Moses Mendelssohn (1729-1786). ${ }^{4}$

Wach semasa kecilnya amat di sayang oleh dan bukan dari kedua orang tuanya tetapi juga dari kakek dan neneknya dari pihak ayah ataupun ibu. Mereka semua adalah orang-orang yang berbudaya tinggi. Rumah-rumah mereka kerap kali dikunjungi oleh para serjana yang terkenal, para artis diplomat, dan ahli-ahli kenegaraan. Sejak awal masa kanak-kanaknya Wach sudah tertarik dengan music, satra dan puisi, bahasa kelasik serta bahasa-bahasa asing modern. 
Dengan imajinasinya yang hidup telah mencip sebuah negri fantasi yang di sebutnya "pelagipten", segala kata yang mencakup segala jenis dan keindahan jabatan politik dan keagamaan.

Wach minatnya terhadap agama bermula ketika dia masih belia. Gurunya, seorang wanita penganut agama Katolik Romawi yang taat, suatu ketika mengajaknya beraudiensi dengan Bishop di Wurzburg. Di sana ia diberi beberapa buah gambaran

${ }^{5}$ Wach menginjak pada pendidikkan menengahnya diperoleh di Vitzthumsche Gimnasium di Dresden di mana dia lulis ujianakhir pada tahun 1916. Dalam tahun yang sama, pada usia delapan belass tahun, Wach memassuki tentara Jerman ssebagai Letnan dan dikirim ke Pront Rusia. Di kemudian hari Wach sering berkelekar bahwa pengetahuannya mengenai bahasa Rusia dan bahasa Arab merupakan hasil sampingan dari perang. Sesuasai perang Dunia I, dia mngajar sebentar di Universitas Leipzig dan menghabiskan tahun 1919 di Munich. Sesuadah satu kwartal kegiatan akademis di Berlin (1920), Wach kembali ke Leipzig untuk tinggal selama lebih dari dua tahun. Wach memperoleh gelara Doktor ilmu Filsafat pada tahun 1922. Kemudian Wach mengambil sejarah agama sebagai mata pelajaran tambahan pokok, filsafat agamaagama dan studi ketimuran sebagai mata pelajaran tambahan. Tetapi nauliri intelektualnya mendesak harus mengikuti kuliah kedokteran psikiater dan juga seni.

Pandangan Wach terhadap agama ditentukan oleh latar belakang keluarga dan pengalaman pribadi. Dalam persoalan keagamaan dia mewarisi sikap toleransi (irenic) keluarga dan lingkungan sekitarnya. Memori Moses Mendelshon di hormati oleh anak-cucunya. Bahkan meskipun putranya, Abraham, mempunyai anak-anak yang di baptis di Greja Lutheran, dan Felix Mendelssohn, cucu laki-laki Moses dan anak dari Abraham mengawini putra seorang pemuka greja Reformasi, namun semangat Nathan der Weise tetap hidup dalam keluarga Wach sampai hari ini. Universitass Leifzig, almamater Gothe, Klopstock, dan Shelling menyumbangkan pula sifat toleransi kepada diri Wach. ${ }^{6}$

\section{Pengertian dan Hakekat Pengalaman Keagamaan Menurut Joachim Wach}

Berbicara tentang pengalaman keagamaan, tentu saja sangat terkait dengan manusia yang nota bene adalah pelaku atau pelaksana dari ajaran atau doktrin dari sebuah agama. Hal ini bearti pengalaman keagamaan hanya akan diperoleh oleh manusia yang melaksanakan ajaran agamanya, tanpa itu maka seseorang akan sangat sulit untuk memahami dan memperoleh pengalaman keagamaan. Hal seperti ini sebagaimana ungkapan Joachim Wach yang memberikan pengertian "pengalaman keagamaan adalah merupakan aspek batiniah dari saling hubungan antara manusia dan fikirannya dengan Tuhan". ${ }^{7}$ Menurut Zakiah Darajat hubungan batin seseorang dengan Allah Swt di dalam ilmu jiwa dinamakan pengalaman keagamaan. ${ }^{8}$

Jadi tegasnya, pengalaman keagamaan merupakan aktivitas manusia dalam keberhadapannya dengan Sang 
Pencipta. Aktivitas tersebut akan meliputi segi bathiniah dan lahiriah sehingga oleh karenanya manusia akan mengembangkan hubungan dengan Tuhan tersebut dalam bentuk polapola perasaan yang sistem-sistem pemikiran (keyakinan religious, ajaran agama, mitos dan dogma), sistem kelakuan sosial ( upacara sembahyang bersama, ritus, liturgi) dan organisasi-organisasi dengan orang lain akan terasa berbeda karena pengalaman keagamaan seseorang dengan orang lain akan terasa berbeda, karena pengalaman keagamaan merupakan aspek bathiniah seseorang sehingga akan terasa seolah-olah kondisi subjektif tersebut sangat dominan, namun sesungguhnya bukanlah perihal yang subjektif yang dikehendaki dalam penelitian ini tetapi aspek universal dari pengalaman keagamaan yang dirasakan.

Dengan pengertian tersebut dapat dipahami bahwa pengalaman keagamaan merupakan hubungan bathin seseorang terhadap suatu kekuatan supranatural (Tuhan), hubungan tersebut dapat diciptakan dalam bentuk pikiran dan perasaan dengan cara melaksanakan ajaran-ajaran agama dan semua bentuk ritual keagamaan. Pengalaman keagamaan setiap orang akan berbeda, karena perbedaan tingkat pengalaman keagamaan ajaran agama yang dilakukan oleh orang tersebut, merupakan pengalaman yang bersifat individu dan dapat dirasakan oleh orang yang mengalami. Pengalaman keagamaan pada hakekatnya merupakan pengalaman rohani, orang yang mengalami masalah tersebut merasakan seolah-olah mampu menjangkau zat yang maha gaib dan maha suci (Tuhan) yang berada di luar alam nyata dengan melaksanakan ajaran agama.

Menurut Joachim Wach ada dua cara untuk meneliti hakekat pengalaman keagamaan yaitu: ${ }^{9}$

a. Menggunakan deskripsi sejarah agama, sekte atau aliran pemikiran keagamaan itu sendiri.

b. Dengan menelusuri pengalaman seorang baik pengalaman pribadi maupun pengalaman kolektif.

Dari sini dapat diketahui bahwa pengalaman keagamaan itu memang benarbenar ada, meskipun tidak dapat dipisahkan dari pengalaman manusia pada umumnya. Menurut Wach, agar menjadi pengalaman yang terstruktur, pengalaman keagamaan memerlukan 4 macam kriteria: ${ }^{10}$

a. Pengalaman tersebut merupakan respon terhadap suatu yang dipandang sebagai realitas mutlak.

b. Pengalaman tersebut melibatkan pribadi secara utuh (integral), baik pikiran, emosi maupun kehendaknya.

c. Pengalaman tersebut memiliki intensitas yang mengatasi pengalaman-pengalaman manusia yang lainnya.

d. Pengalaman tersebut dinyatakan dalam perbuatan karena memiliki sifat imperatif dan merupakan sumber utama motivasi dan perbuatan.

Berdasarkan hal di atas maka dapat disimpulkan bahwa yang dimaksud dengan pengalaman keagamaan adalah hubungan batin atau aspek bathiniah antara manusia dengan fikirannya terhadap Tuhan dan hubungan batin tersebut ditimbulkan karena melaksanakan ajaran-ajaran agamanya 
dengan semua bentuk praktik keagamaan seperti sholat, puasa, doa-doa dan sebagainya.

\section{Ekspresi Pengalaman Keagamaan Joacim Wach}

Menurut Joachim Wach, bentuk ekspresi pengalaman keagamaan ada tiga yaitu:

1. Ungkapan pengalaman keagamaan dalam bentuk pemikiran

Pengalaman keagamaan diungkapkan secara intelektual bisa bersifat spontan belum mantap atau baku dan tradisional. Ungkapan pengalaman tidak akan serupa dalam pengungkapannya sesuai dengan ragam kebudayaan, sosial dan agama yang ada. Ungkapan tersebut dapat bersifat Teologis (Tuhan) yaitu mengungkapkan tentang hakikat Tuhan, asal-usul, perkembangan, sifat serta hubungan manusia dengan Tuhan.

Ungkapan pengalaman keagamaan dalam bentuk pemikiran lainnya dalam bentuk doktrin yang diturunkan sendiri oleh yang kudus, yang lebih dimaknai oleh wahyu yang mutlak, himpunan doktrin itu oleh agama disebut dengan kitab suci. Lebih jauh Joachim Wach menegaskan doktrin mempunyai tiga fungsi yang berbeda-beda, penegasan dan penjelasan iman, pengetahuan dengan ilmu lain (Apologetik). ${ }^{11}$ Ungkapan pengalaman keagamaan yang berbentuk teoritis terdapat dalam doa yang merupakan sarana pengungkapan gejolak hati terhadap permasalahan yang dihadapi, yang merupakan sebuah keterkaitan dalam berhubungan dengan Tuhan sebagai bukti kelemahan manusia sebagai makhluk ciptaan-Nya.

Pengalaman keagamaan dalam bentuk pemikiran memiliki beberapa motivasi untuk diungkapkan, yaitu:

a. Adanya suatu sifat yang eksplosif, yaitu yang menggebu-gebu dari sesorang yang mengalami pengalaman keagamaan untuk mengungkapkan pengalamannya. Orang pasti akan memperlihatkan perasaan gembira dan susah. Demikian pula dengan perasaanperasaan yang lainnya.

b. Pengalaman keagamaan itu bersifat propagandistic. Adanya suatu dorongan yang kuat bukan saja dirasakan untuk ikut ambil bagian, teapi juga untuk memikat dan mengajak fihak lain agar melihat dan mendengar seperti a pa yang telah dilihat dan didengar oleh seseorang. Dorongan ini kadang-kadan sedemikian kuat sehingga mampu mempengaruhi dan menguasai individu-indivdu dan kelompokkelompok, bukan melalui kekuatan pesan yang disampaikan tetapi semata-mata melaui kemampuan dari para pembawa pesan tersebut.

c. Pengalaman keagamaan yang sifatnya subjektif, cbatini dan individual, telah menunjukkan bahwa pengalaman keagamaan itu hanya bisa diungkapkan jika 
seseorang yang mengalami pengalaman keagamaan mampu memahami dirinya tatkala mengalami perasaan di luar jangkauannya.

2. Ungkapan pengalaman keagamaan dalam bentuk perbuatan

Ungkapan pengalaman keagamaan dalam bentuk perbuatan, mengandung arti bahwa pengalaman yang terjadi merupakan hasil dari adanya pemahaman tentang Tuhan, manusia, dan alam yang didapatnya melalui proses pemikiran terlebih dahulu. Dimana pengalaman keagamaan dalam bentuk perbuatan akan terungkapkan melalui; mengabdikan diri atau beribadah, mendekatkan diri atau memohonkan sesuatu kepada Tuhannya, menguasai atau mengontrol Tuhan supaya melakukan apa yang di inginkan oleh manusia, mensyukuri karuia atau nikmat Tuhan, memberikan santunan atau hadiah Tuhan, memberikan pelayanan pada sesama umat manusia. Dari semuanya itu dimaksudkan sebagai usaha unutk menjalankan segala perintah dari Tuhan yang telah dibebankan kepadanya.

Tingkah laku agama yang pertama dan utama, menurut Von Hugel, “adalah pemujaan...” Dari satu segi, kultus dapat dijelaskan sebagai sebuah reaksi penghayatan terhadap Realitas Mutlak atau tertinggi. “Tuhan datang kepada manusia ketika manusia mendekati Tuhan.” Dalam pengalaman keagamaan, dalam diri manusia munvul rasa kedaran merendahkan diri sehingga bukan d ia yang memperkokoh suatu hubungan atau komuni tetapi dialah yang diperkokoh oleh dan melalui pelaksanaan praktek keagamaan. Manusia akan menjadi manusia melalui perbuatan-perbuatan ini, yang akan memperbaiki dirinya menuju hakikat dan nasnibnya yang sebenar-benarnya.

Jadi, kultus atau ungkapan pengalaman keagamaan dalam bentuk yang nyata adalah merupakan suatu tanggapan total atas wujud total mendalam dan integral. Realitas Mutlak, dalam bentuk perbuatan. Menurut Scheler, "kesadaran beragama adalah suatu pemahaman yang tidak timbul seluruhnya mendahului ungkapan kultisnya".

Kedua, bentuk ungkapan pengalaman kegamaan yang nyata (praktis) adalah bakti atau peribadatan dan pelayanan. Kedua-duanya saling pengaruh mempengaruhi. Apa yang difahami sebagai realitas tertinggi akan desembah melalui suatu tingkah laku pemujaan, dan dilayani dalam bentuk tanggap terhadap ajakan dan kewajuban untuk masuk ke dalam persekutuan Tuhan.

Setiap agama mempunyai praktek-praktek peribadatannya sendiri-sendiri. Joachim Wach mengutip kembali pernyataan Underhill yang indah, yang telah disinggung dalam karyanya yang dahulu: manusia yang didorong oleh Tuhan, sadar atau tidak sadar dorongan 
Tuhan yang tersembunyi itu, menanggapi-Nya denngan cara yang terbaik bukan melalui suatu gerak akal yang sederhana, teapi melalui suatu perbuatan yang banak dan kompleks, di mana s eluruh sifatnya diperhatikan, dan yang dalam perkembangannya yang sempurna menyerupai sifat-sifat karya seni. $^{12}$

Adanya kesadaran manusia akan segala sesuatu yang muncul dalam kehidupannya tidak hanya ditanggapi lewat akalnya saja, teapi adanya kecenderungan manusia untuk mengaktualisasikan pemahamannya tentang sesuatu hal itu dalam bentuk perbuatan yang nyata. Hal ini dimungkinkan bahwa pengalaman keagmaan dal bentuk perbuatan menuntut suatu aktifitas dari manusia itu sendiri, sehingga bukan hanya anganangan saja yang ada dalam benak manusia itu, tetapi juga lebih konkrit untuk dilaksanakan dalam bentuk yang nyata yaitu perbuatan.

Kita telah mengetahui bahwa ketaan dan peribadatan adalah dua bentuk dari ungkapan pengalaman keagamaan yang nyata. Peribadatan hendaknya difahami dalam pengertiannya yang paling luas. Karena itu dapat dikatakan bahwa " suatu perbuatan murah hati yang tertentu akan dapat menjadi suatu alat bantu untuk melaksanakan ibadat apabila bukan ibadat itu sendiri. Dalam menghadapi realitas Mutlak, manusia sadar terhadap adanya kewajiban yang dibebankan atas dirinya oleh sifatnya yang asli yang difahami dari segi keberhadapan ini. ${ }^{13}$

Manusia yang beragama tentu tidak terlepas dari kedua perbuatan tersebut, yaitu ketaatan dan peribadatan, karena setiap agama yang mempunyai ajaran-ajaran mewajibkan umatnya untuk melaksanakan segala sesuatu yang d iperintahkannya, sehingga tidak ada alasan mausia yang beragama tidak melakukan perbuatan tersebut.

Pengalaman keagamaan dalam bentuk perbuatan dapat dibedakan dengan pengalaman keagamaan yang lain, karena di dalamnya terjadi suatu pergantian eksistensi...ia adalah hasil pemantapan dari perubahan, dan dalam masing-masing hal tersebut dia bukan semata-mata merupakan sebuah rencana untuk berbuat, tetapi perbuatan itu sendiri. Ibadat terdiri dari segala sesuatu yang terdapat dalam tingkah laku kehidupan semacam itu.

Ungkapan pengalaman keagamaan dalam bentuk perbuatan memiliki pola sebagai berikut:

a. Berkenaan dengan tempat, artinya dimana pengalaman keagamaan itu berlangsung. Sebagai contoh, misalkan; di dekat sumber mata air, di sa mping batu yang besar, di bawah pohon tertentu, di tempattempat keramat (istimewa), di dalam sebuah bangunan, di atas tanbah yang di batasi oleh sebuah tanda, dan lain sebagainya.

b. Berkenaan dengan waktu, artinya kapan pengalaman keagamaan itu berlangsung atau terjadi. Misalnya; 
pada malam hari, ketika menyendiri atau menyepi, dan lain sebagainya.

c. Berkenaan dengan cara atau proses, artinya bagaimana proses pengalaman keagamaan itu berlangsung. Misalnya; dengan cara bermimpi, berziarah, dan lain sebagainya.

Pengalaman keagamaan dalam bentuk perbuatan secara praktis mempunyai hubungan yang sangat erat sekali dengan ungkapan pengalaman keagamaan dalam bentuk pemikiran dalam hal ini merupakan hakekat pengalaman keagamaan yang sebenarnya sebagai suatu keberhadapan manusia dengan realitas mutlak. Pengkultusan merupakan bentuk pengungkapan dari setiap gerak keberagamaan seseorang dapat dipandang sebagai tingkah laku keagamaan yang dipergunakan untuk memperoleh dan memelihara hubungannya dengan Tuhan, seperti pemujaan atau kultus.

Menurut Joachim Wach "tingkah laku keagamaan akan membawa pada pertanyaan penting yang perlu dijawab sehubungan pengungkapan pengalaman keagamaan dalam bentuk perbuatan, pertanyaan tersebut meliputi kapan, dimana, bagaimana dan oleh siapa dilakukannya aktifitas pemujaan dan pengorbanan". ${ }^{14}$
Kedua hal tersebut sangat erat hubungannya sehingga perlu adanya keseimbangan, karena apabila tidak terdapat keseimbangan dalam pelaksanannya maka ada dua macam bahaya, bila dalam perbuatannya penekanan terlalu diberikan pada bentuk pertama kemungkinan sikap eksternalisasi dan institusionalisasi, disuatu pihak dan pihak yang kedua bisa menjadi sikap spiritualisme ekstrim apabila bentuk lahiriah ditolak.

3. Ungkapan pengalaman keagamaan dalam bentuk persekutuan

Kelompok keagamaan terbentuk dalam dan melalui perbuatan keagamaan. setiap agama mengembangkan suatu bentuk persekutuan keagamaan. Cara yang digunakan oleh anggota kelompok keagamaan dalam menghayati Tuhan, membayangkan dan berhubungan dengannya mengalami persekutuaan membayangkan dan mempraktekkannya, menentukan hakekat dan bentuk organisasi suatu kelompok keagamaan. karenanya kelompok keagamaan mempunyai hukuman tersendiri pandangan hidup, sikap dan suasana tersendiri.

Dalam suatu masyarakat agama terdapat perbedaan antara para anggotanya hal tersebut disebabkan adanya faktor yang menimbulkan perbedaan tersebut antara lain : kharisma, usia, jenis kelamin. Dengan demikian ungkapan pengalaman dalam 
bentuk perbuatan menghantarkan manusia membentuk persekutuan keagamaan. Agama mempengaruhi masyarakat untuk membentuk kelompok dalam beragama manusia secara perorangan dan kolektif berhubungan dengan Tuhan dan saling berhubungan dengan manusia

keberadaan kelompok agama sudah merupakan suatu kewajaran dalam kehidupan beragama, sehingga agama tidak lagi milik perorangan saja, tetapi bagaimana agama sudah merupakan milik bersama atau milik suatu kelompok.

Kita bisa membedakan antara pengalaman keagamaan perorangan dengan pengalaman keagamaan kelompok, kalau pengalaman perorangan, hubungan yang disebut kemudian adalah yang pertamatama timbul, tetapi secara ontologism hubungan tersebut bergantung pada pemikiran terhadap Tuhan. Dan pengalaman kelompok keagamaan bergantung pada cara yang dipergunakan oleh para anggotanga dalam menghayati Tuhan, membayangkan dan berhubungan dengan-Nya, dan bergantung pada cara mereka mengalami persekutuan, membayangkannya dan memperaktekannya. ${ }^{15}$

Bisa dilihat bagaimana perbedaan yang nampak antara penbgalaman keagamaan yang bersifat perorangan dengan yang kelompok, ini menunjukkan bahwa suatu pengalaman tentunya melibatkan perasaan dari orang yang mengalaminya, dan apabila hal tersebut menimpa kelompok agama, maka pengalamannya tentang agama tentu dirasakan oleh anggota kelompok yang lain, sehingga kebersamaan dalam kelompok tersebut akan nampak.

Adapun suatu kelompok bisa dikatakan sebagai bentuk persekutuan, apabila antara anggota yang satu dengan yang lain saling mengenal, sehingga para anggota mempunyai cirri kedalaman perasaan yang tinggi, solidaritas yang kuat, dan aktivitas yang babnyak. Apabila ukuran tersebut lebih besar tetapi belum di batasi oleh kriteria semisal kelahiran, local, dan lain sebagainya, maka sifat masyarakat tersebut akan berbeda-beda.

Ada beberapa faktor yang melahirkan suatu kelompok, faktor tersebut ada yang bersifat faktor agama, an faktor di luar agama. Faktor agama adanya bakatbakat spiritual seperti penyembahan dan pengajaran adalah contoh-contoh faktor agamis, usia, kedududkan sosial, etika, dan latarbelakang keturunan adalah kualifikasikualifikasi yang bersifat non agamis.

Kemudian ada empat macam, faktor yang menimbulkan perbedaan dalam suatu masyarakat agama. Pertama adalah perbedaan dalam fungsi. Dalam suatu kelompok yang kecil hanya terdiri beberapa orang anggota yang dipersatukan oleh ikatan pengalaman keagamaan bersama akan terdapat perbedaan tertentu dalam pembagian fungsi. Di samping fungsi tersebut hanya sesuai untuk orang-orang yang sudah cukup usia atau yang sangat berpengalaman dalam memimpin doa atau nyayi, maka para anggota yang lebih muda dibebani dengan persyaratan material yang akan dipergunakan untuk tujuan-tujuan kurban. 
Kedua, dalam kelompok-kelompok keagamaan pula perbedaan yang didasarkan atas karisma. Dalam masyarakat yang sangat egalitarian sekali pun, juga terdapat adanya pengakuan terhadap perbedaanperbedaan dalam kekuasaan, prestise, dan kedudukan dalam masyarakat. Karisma tertinggi yang dapat diangankan dan mungkin dimiliki oleh seseorang atas dasar seseorang atas dasar humen atau tuhan. Untuk itu kekuatan-kekuatan yang luar biasa hanya diberikan kepada orang yang diberkati, dan dengan perwujudan pelaksanaan kekuatan tersebut tanpa batas.

Faktor ketiga, yang membedakan adanya perbedan dalam kelompokkelompok keagamaan adalah perbedaan alami berdasarkan usia, jenis kelamin, dan keturunan. Karena adalah tertentu, kelompok yang muda dan juga tua agak sedikit dipisahkan dan masing-masing memainkan peranan sendiri-sendiri dalam kehidupan masyarakat agama baik secara perorangan ataupun kelompok.

Keempat, perbedaan berdasarkan status. Prinsip ini dipandang sebagai suatu kombinasi dari sejumlah factor yang telah menimbulkan perbedaan di atas, pemikiran yang "demokratis" tentang persamaan hak semua pemeluk agama baru muncul kemudian dalam sejarah agamaagama, dan terus terang, dalam prakteknya jarang sekali dilaksanakan.

Ungkapan pengalaman keagamaan dalam persekutuan ternyata, melahirkan berbagai jenis kelompok keagamaan, hal ini karena kelompok keagamaan yang ada merupakan suatu proses dari adanya pengalaman keagamaan dalam bentuk pemikiran dan perbuatan, sehingga keberadaannya senantiasa mencerminkan dari latarbelakang mereka membentuk suatu kelompok keagamaan.

\section{Penutup}

Demikian, pengalaman keagamaan menurut Joachim Wach adalah aspek batiniah dari saling hubungan antara manusia dan fikirannya dengan Tuhan Pengalaman keagamaan diekspresikan dalam tiga hal yaitu ungkapan pengalaman keagamaan dalam bentuk pemikiran berupa doktrin keagamaan, ungkapan dalam bentuk perbuatan berupa peribadatan dan ungkapan dalam bentuk persekutuan berupa kelompok-kelompok keagamaan.

\section{Endnote}

${ }^{1}$ Dadang Kahmad, Metode Penelitian Agama, (Bandung:Pustaka Setia,2000), h.29.

${ }^{2}$ Joachim Wach, Ilmu Perbandingan Agama, (Jakarta :PT.Rajawali,1989) cet ke-2 h. 25.

${ }^{3}$ Zakiah Daradjat, Ilmu Jiwa Agama, (Jakarta: Bulan Bintang, 1970), h. 12-15.

4 Joachim Wach, Ilmu Perbandingan Agama,h. XVI.

5 Joachim Wach, Ilmu Perbandingan Agama,h. XVII.

${ }^{6}$ Joachim Wach, Ilmu Perbandingan Agama,h. XI. h.61.

${ }^{7}$ Joachim Wach, Ilmu Perbandingan Agama,

${ }^{8}$ Zakiah Darajat, Ilmu Jiwa Agama,(Jakarta:Bulan Bintang,1988), h. 25.

${ }^{9}$ Joachim Wach, Ilmu Perbandingan Agama, Inti dan Bentuk Pengalaman Keagamaan, h. 40.

${ }^{10}$ Joachim Wach, Ilmu Perbandingan Agama, Inti dan Bentuk Pengalaman Keagamaan, h. 50.

${ }^{11}$ Joachim Wach, Ilmu Perbandingan Agama, Inti dan Bentuk Pengalaman Keagamaan, h. 99.

${ }^{12}$ Adeng Muchtar Ghazali, Ilmu Perbandingan Agama, (Bandung: Pustaka Setia, 2000), h. 154.

${ }^{13}$ Adeng Muchtar Ghazali, Ilmu Perbandingan Agama, h. 173.

${ }^{14}$ Joachim Wach, Ilmu Perbandingan Agama, Inti dan Bentuk Pengalaman Keagamaan, h. 100. ${ }^{15}$ Adeng Muchtar Ghazali, Ilmu Perbandingan Agama, h. 189. 